\title{
Inheritance of a hair character in Helianthemum oelandicum var. canescens and allele frequencies in natural populations
}

\author{
Björn Widén ${ }^{1}$ (I)
}

Received: 20 December 2016 / Accepted: 6 September 2017 / Published online: 25 September 2017

(C) The Author(s) 2017. This article is an open access publication

\begin{abstract}
Helianthemum oelandicum var. canescens (Hartm.) Fr. is an endemic taxon with a restricted distribution (less than $10 \mathrm{~km}^{2}$ ) in the southernmost part of the Baltic island of Öland, SE, Sweden. The taxon varies with respect to stellate hairs. Most plants can be classified into two morphs, the stellated morph (with a dense carpet of stellate hairs on the abaxial surface of the leaves) and the bristled morph (without a carpet of stellate hairs). In crosses between plants assumed to be homozygous for the trait that characterises the phenotypes of the two morphs, F1 offspring was indistinguishable from the bristled morph. Segregation in F2 did not deviate from the expected 3:1 ratio (bristled morph/stellated morph), indicating one major gene with a dominant allele for the phenotype of the bristled morph and a recessive allele for the phenotype of the stellated morph. Besides the Mendelian inheritance of the presence/ absence of a whitish cover of stellate hairs, the density of hairs appeared to be further modified by quantitative genes. The frequency of the recessive allele for the phenotype of the stellated morph varied among populations and showed a geographical structure. Possible mechanisms behind the spatial variation in indumentum are discussed.
\end{abstract}

Keywords Allele frequency $\cdot$ Helianthemum $\cdot$ Major gene $\cdot$ Mendelian inheritance $\cdot$ Pubescence

Handling editor: Andreas Tribsch.

Björn Widén

bjorn.widen@biol.lu.se

1 Department of Biology, Section Biodiversity, Lund University, Sölvegatan 37, 22332 Lund, Sweden

\section{Introduction}

Hairs are conspicuous morphological traits that often show polymorphism in plants (Levin 1973). A range of adaptive advantages has been suggested to explain this polymorphism; hairs can play a role in the plant defence against herbivores and pathogens (Hagley et al. 1980; Ågren and Schemske 1993; Paliniswamy and Bodnaryk 1994; Westerbergh and Nyberg 1995; Meagher et al. 1997; Løe et al. 2007) and in the protection from abiotic stresses by temperature and water regulation and UV reflectance (Skaltsa et al. 1994; Espigares and Peco 1995; Wagner et al. 2004). Hair density is often under some genetic control, revealed by crosses between species within a genus or between morphs within species (Ågren and Schemske 1992; Paliniswamy and Bodnaryk 1994). The spacing and number of hairs can have a complicated genetic background (Larkin et al. 1996), but an increasing number of studies have shown that hairiness on different parts of the plant is governed by simple Mendelian genes (Westerberg 1992; Silvestre 2000; Kärkkäinen and Ågren 2002; Kivmäki et al. 2007; Yol and Uzun 2011; Widén 2015).

Hairs are often used as marker traits in crop plants or as diagnostic keys in the taxonomy of several plant families, e.g. Malvaceae, Cistaceae (Janchen 1907; Bayer and Kubitzki 2003). Helianthemum is a young genus (Guzmán and Vargas 2009; Aparicio et al. 2017) with a number of variable species complexes that have not yet reached reproductive isolation (cf. Widén 1986, 2015). Common to many of these complexes is an intricate differentiation in pubescence (Grosser 1903; Proctor and Heywood 1968). Widén (2015) has recently shown that the presence of a dense cover of stellate hairs on the abaxial surface of the leaves is governed by a recessive allele of a Mendelian gene in one species of the genus-Helianthemum 
nummularium (L.) Mill. To understand the evolutionary mechanisms behind the diversity of hair morphs in Helianthemum, more studies of various taxa are needed.

Helianthemum oelandicum (L.) Dum.Cours. is an aggregate of morphs that has been divided into a number of geographical and altitudinal taxa in Europe, North Africa and the Caucasus (Janchen 1907; Proctor and Heywood 1968; Widén 2010). Three kinds of hairs are found in $H$. oelandicum-bristles, stellate hairs and glandular hairs (Grosser 1903). Bristles and stellate hairs are found on leaves, peduncles and sepals. Bristles usually consist of 2-3 hairs united at the base and pointing in the same direction, whereas the 4-15 united arms in stellate hairs radiate from the base. Intermediates between bristles and stellate hairs occur.

The most important diagnostic characters used to circumscribe taxa in the complex, apart from size of leaves and petals, are the absence or presence of a dense cover of stellate hairs on the abaxial surface of the leaves and flowering phenology. Flowering phenology has a morphological basis (Widén 1980); inflorescences are produced only on the previous year's growth in plants with the concentrated flowering $(\mathrm{CF})$ phenology giving rise to a short flowering period early in the season. In plants with the protracted flowering (PF) phenology, inflorescences are borne on both the previous and the current year's growth, resulting in a potential flowering throughout the season (Widén 1980).

The $H$. oelandicum complex is represented by the endemic subspecies oelandicum with two varieties in the very restricted geographical area (about $1350 \mathrm{~km}^{2}$ ) of the Baltic island of Öland (Widén 2010). The taxa on Öland are important for understanding the evolution of traits in the complex, since their morphological variation covers the whole range of variation found in the two main diagnostic characters in the rest of the complex (flowering phenology and pubescence). Helianthemum oelandicum subsp. oelandicum var. oelandicum is characterised by CF phenology and lack of a dense cover of stellate hairs on the abaxial surface of the leaves (with or without bristles), while $H$. oelandicum subsp. oelandicum var. canescens (Hartm.) Fr. consists of PF plants with or without a dense cover of stellate hairs on the abaxial surface of the leaves (but always with bristles). The two varieties have mainly allopatric distributions in the area of steppe-like 'alvar' grasslands on the Baltic island of Öland, Sweden; var. oelandicum is common in suitable habitats throughout the island except for the area of var. canescens, in the southernmost part of the island (Fig. 1). Widén (1988) described, in detail, variation in the density of hairs and the correlation between types of hairs in different parts of the plant. Both varieties show a significant spatial pattern in pubescence that, according to Widén (1980, 1988, 2010), reflects the heterogeneity of their habitats; hairy plants are more frequent in dry, well-drained habitats, whereas less hairy plants are more common in less-drained habitats with freezing and thawing during winter (cf. Sterner 1936a).

The Baltic island of Öland was covered by ice during the LGM (Svendsen et al. 2004). Pollen records show that $H$. oelandicum immigrated soon after the withdrawal of the ice (Königsson 1968; Berglund 1966; Mortensen et al. 2011). The pollen spectra indicate that $H$. oelandicum was abundant early in the postglacial history of the island, but became rare as forests developed (Königsson 1968). The species probably existed in small isolated pockets on exposed bedrocks in closed forests for several thousand years. The human Neolithic influences (7000-4000 years ago) opened up the landscape, and this is reflected in increasing pollen records of $H$. oelandicum (Königsson 1968).

A recent phylogeographic study based on plastid microsatellites indicated that the species reached Öland via two migration routes, one from the south-south-west and one from the south-east. The distribution of two plastid haplotypes on Öland showed a distinct geographical pattern, which did not correspond to the spatial distribution of the two varieties and the variation in pubescence (Soubani 2010). This indicates extensive introgression between two migration lineages and a postglacial adaptation to different habitats on Öland (Widén, in prep.). Consequently, the spatial differentiation in pubescence of $H$. oelandicum on the Baltic island of Öland has developed during the past 10,000 years (Widén 1988). Variation in pubescence of $H$. oelandicum on Öland has a corresponding differentiation in pubescence in the continental part of the distribution of the $\mathrm{H}$. oelandicum complex, with an older and more intricate glacial and postglacial migration history (Soubani 2010).

The present study is the second in a series dealing with the genetics behind variation in pubescence of Helianthemum (cf. Widén 2015). Here I report on (1) the result of a crossing programme to unravel the genetics of the presence of a dense cover of stellate hairs on the abaxial surface of the leaves in H. oelandicum var. canescens. This trait has long been used as a diagnostic character in the species complex (Janchen 1907; Proctor and Heywood 1968), but Widén (2010) abandoned it as a diagnostic character for $H$. oelandicum on the Baltic island of Öland. Here I also (2) translate the geographical pattern in the hair character into allele frequencies in natural populations of $H$. oelandicum var. canescens, based on data in Widén (1988). Allele frequencies in natural populations will be the basis for further studies of the adaptive significance of genetic variation for pubescence (cf. Widén 1980, 1988). 


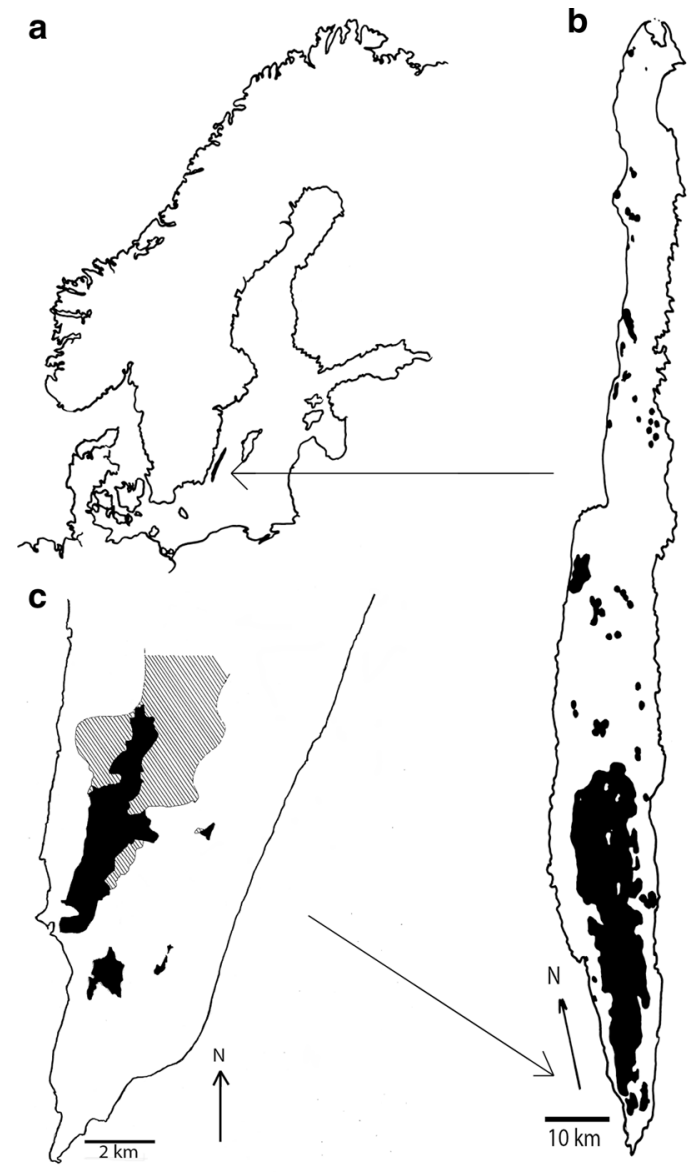

Fig. 1 a The Baltic area. b The distribution of Helianthemum oelandicum (black) on the Baltic island of Öland (simplified from Sterner 1936a, b). c The distribution of $H$. oelandicum on the southernmost part of the Baltic island of Öland. Black indicates the area where $>90 \%$ of the plants belong to var. canescens and stripes indicate the distribution of var. oelandicum. The boundary between the distributions of the two varieties on the Great Alvar was established with GPS. The area marked with black in the southernmost part of Öland

\section{Materials and methods}

\section{The model species}

Helianthemum oelandicum subsp. oelandicum is a windpollinated (Sterner 1936a; Widén 2010), outcrossing, diploid $(2 n=22)$ dwarf shrub, endemic to the Baltic island of Öland (Sweden). Its main distribution area on the island is the Great Alvar (Fig. 1b), $255 \mathrm{~km}^{2}$ of open, dry grassland habitats on limestone outcrops with thin soils overlaying bedrock $(\leq 20 \mathrm{~cm})$ (Bengtsson et al. 1988; Reitalu et al. 2014). These habitats consist of a complex mosaic of abiotic conditions, such as drought, water logging and frost disturbance during the winter (Sterner 1936a). Helianthemum oelandicum is one of the most common species in

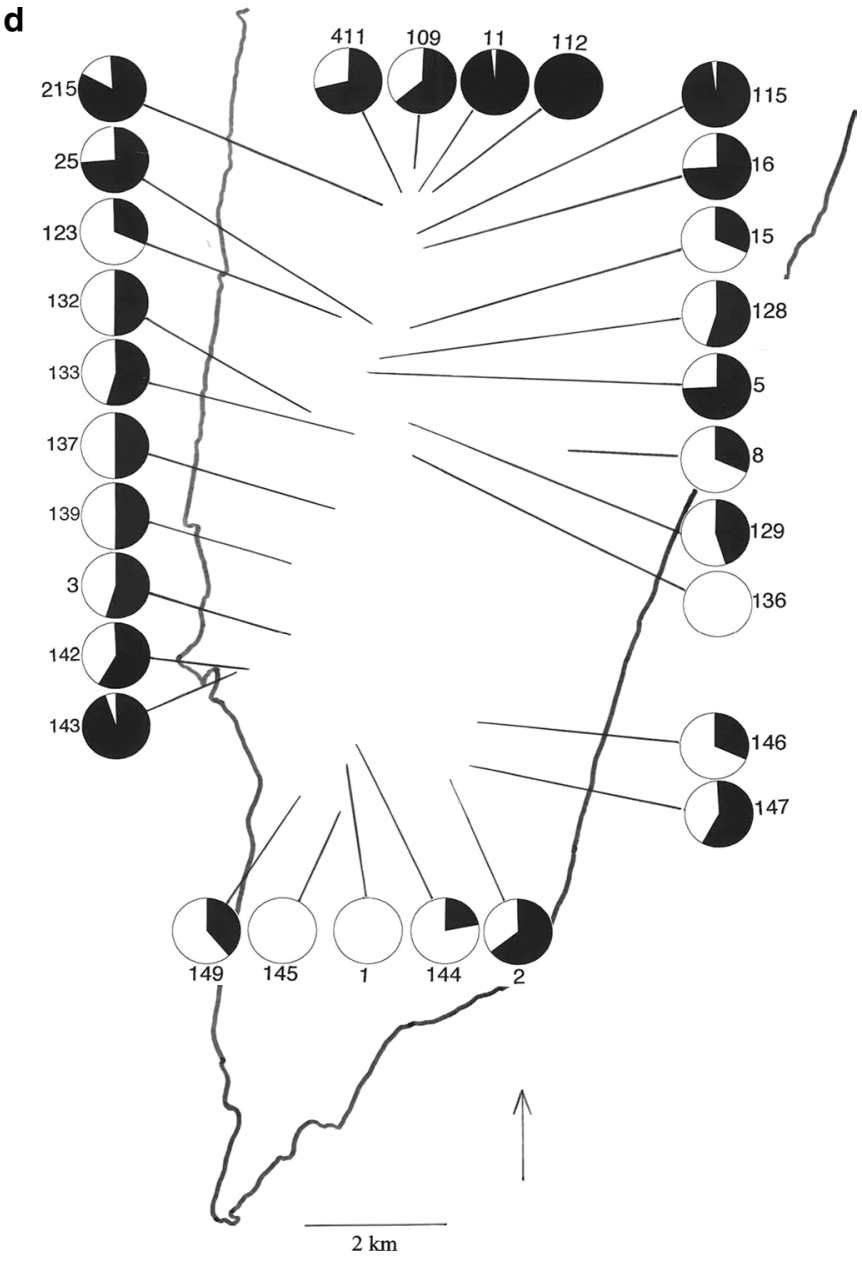

represents the outer border of a number of small more or less isolated populations south of the main distribution of var. canescens on the Great Alvar. d Allele frequencies in natural populations of $H$. oelandicum var. canescens. The pie diagrams show (black) the frequencies of the recessive can allele for a dense cover of stellate hairs on the abaxial surface of the leaves based on field sample 1; cf. Table 7 (population identity next to the diagram)

the dry grassland habitats and can occur in extremely large populations (Widén 1980; Bengtsson et al. 1988).

Helianthemum oelandicum var. canescens is restricted to the southernmost part of Öland, comprising less than $10 \mathrm{~km}^{2}$ (Fig. 1c). The distribution area of var. canescens marked in Fig. 1c was established in 2008 using GPS to find the border between var. canescens and var. oelandicum. The distribution areas of the two varieties on the Great Alvar are often separated by habitats without $H$. oelandicum (Widén 1980), but sometimes a zone where one variety is gradually replaced by the other. The area with more than $90 \%$ of the plants belonging to var. canescens has been marked with black in Fig. 1c (see also Widén 1980). The transition zone between the two varieties will be discussed elsewhere. 


\section{Sampling of plants for survey of variation in pubescence}

The field sampling of the study materials was carried out in the early 1970s and performed in three steps (described in more detail in Widén 1980, 1988). Firstly, sites $(100 \times 100 \mathrm{~m})$ were selected from areas with $H$. oelandicum; these sites were considered as natural populations and were given identity numbers. Secondly, one to three samples of plants were taken from randomly placed squares $(10 \times 10 \mathrm{~m})$ within each site. Thirdly, each sample within a $10 \times 10 \mathrm{~m}$ square consisted of 20 adult plants taken from a randomly selected plot $(1 \times 1 \mathrm{~m})$. If less than 20 plants were found within a $1-\mathrm{m}^{2}$ plot, additional plots were randomly selected within the $100-\mathrm{m}^{2}$ square until the sample size of 20 adults was reached. In this study, I consider 29 sites within the distribution area of var. canescens (Fig. 1c).

From each plant, a voucher consisting of at least one branch with a leaf rosette and inflorescences was preserved in FAA (field samples 1). For a selected number of sites $(100 \times 100 \mathrm{~m})$, an additional square $(10 \times 10 \mathrm{~m})$ was sampled and 20 plants within a plot $(1 \times 1 \mathrm{~m})$ were preserved in FAA (field samples 2) or as dried and pressed material (field sample 3). Plants in field sample 1 at some sites were permanently marked, and seeds were sampled in July-August. The seeds were scarified with sandpaper to break the dormancy (Thanos et al. 1992) and sown in pots (a bulk sample from each population per pot) the following spring. Seedlings were transplanted to individual pots with a standard soil mixture (50 1 commercial soil, 151 sand, 11 chalk and 0.51 long-lasting nutrients) in the autumn and kept outdoors in the following years. After at least 2 years in a common garden at Lund University, vouchers were preserved in FAA for successive morphometric analysis (common garden sample).

\section{Sampling of plants for genetic analysis}

Plants (as cuttings) were transplanted from natural populations of var. canescens (sites selected in the 1970s, see above) to the research garden at Lund University in the mid1990s. The cuttings (one or two 2- to 3-cm-long branches with a terminal leaf rosette) were planted in sand outdoors in early spring, irrigated frequently and transplanted to pots with standard soil when roots developed. Surviving plants were multiplied in the same way during successive years, until the original plants had as many as ten replicates in the early 2000s. The plants were replanted with the standard soil mixture (see above) each summer and kept outdoors as much as possible (indoors only when used in experimental crosses, see below).

\section{Quantification of pubescence}

Here, I only consider stellate hairs on the abaxial surface of the leaves and disregard the fact that the density of stellate hairs shows a strong correlation with density of bristles (Widén 1988). The naked eye can generally distinguish between plants with a dense cover of stellate hairs on the abaxial surface of the leaves and plants without this trait (Fig. 2). However, under a dissecting microscope, it is clear that the density of hairs is more or less continuous.

Using a template to describe the density of hairs, the third to fifth most distal pairs of well-developed leaves on a shoot were classified under a dissecting microscope (cf. Widén 2015). An individual was given a hair score ranging from 0 to 3 to describe the variation in density from no stellate hairs to a dense whitish felt of intertwisted stellate hairs. The criteria for the hair scores were as follows: $0=$ no stellate hairs on the abaxial surface of the leaf (though there are usually bristles, Fig. 3a, b); 1 = scattered, large stellate hairs all over the abaxial leaf surface (Fig. 3c, d); 2 = leaf surface covered by a thin felt of large stellate hairs that cover each other, but the leaf surface can be seen beneath the felt (Fig. 3e, f); $3=$ a dense whitish felt where individual stellate hairs are difficult to distinguish and where the epidermis beneath the carpet of hairs cannot be seen (Fig. 3g, h). Because of the virtually continuous variation, examined specimens often had a density of hairs that fall between two categories in the template, so half scores were also given. When screening the whole material, individual specimens were given any of the seven hair scores $0,0.5,1,1.5,2,2.5$ or 3 .

Since the classification of hairs involved a risk of subjectivity, I tested the stability of the hair scores in the present study by classifying the hairs on the same specimen

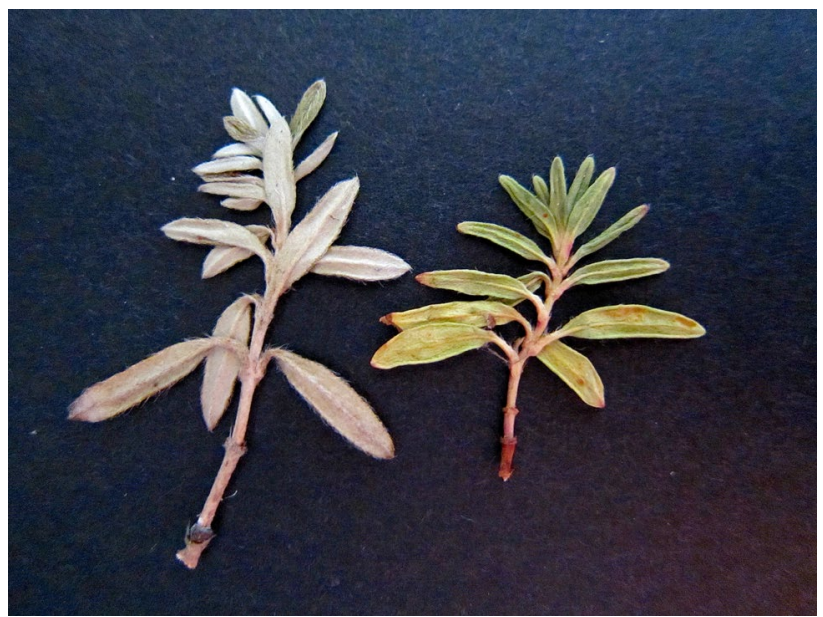

Fig. 2 The abaxial surface the leaves of Helianthemum olandicum var. canescens. To the left, a stellated plant (with a dense cover of stellated hairs) and to the right a bristled plant (without the dense cover of stellate hairs) 
Fig. 3 SEM photographs of scores for stellate hairs on the abaxial surface of the leaves in Helianthemum olandicum var. canescens. Hair score $0(\mathbf{a}, \mathbf{b})$, hair score $1(\mathbf{c}, \mathbf{d})$, hair score $2(\mathbf{e}, \mathbf{f})$ and hair score $3(\mathbf{g}, \mathbf{h})$. The left column shows a $5-\mathrm{mm}$ section of the leaf and the right column shows a close-up of an individual bristle (b) and stellate hairs $(\mathbf{d}, \mathbf{f}, \mathbf{h})$ a

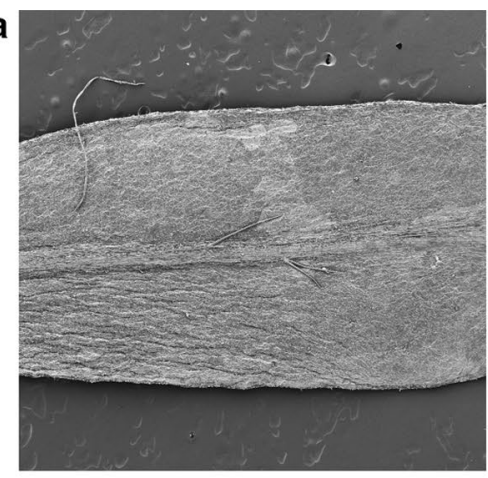

C

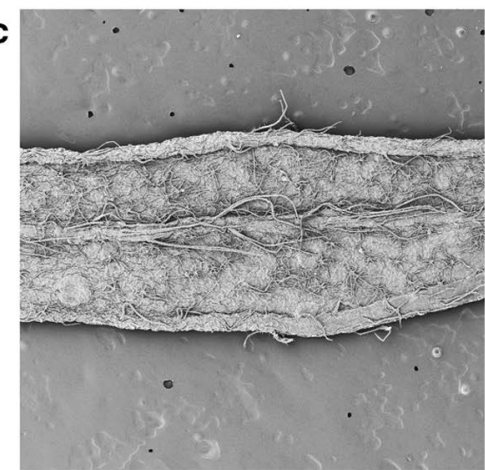

e

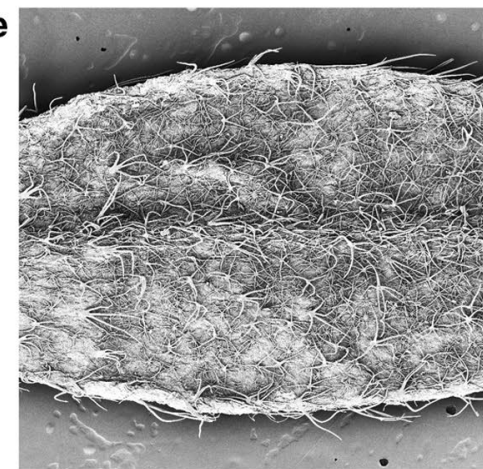

g

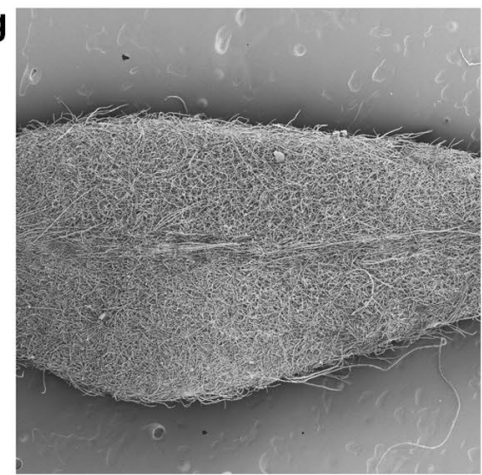

b

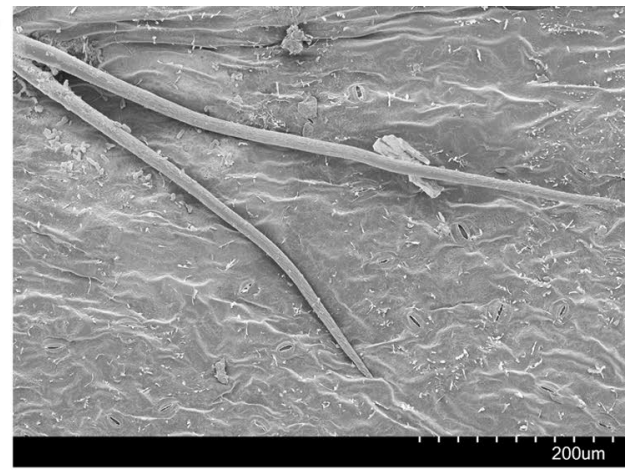

d

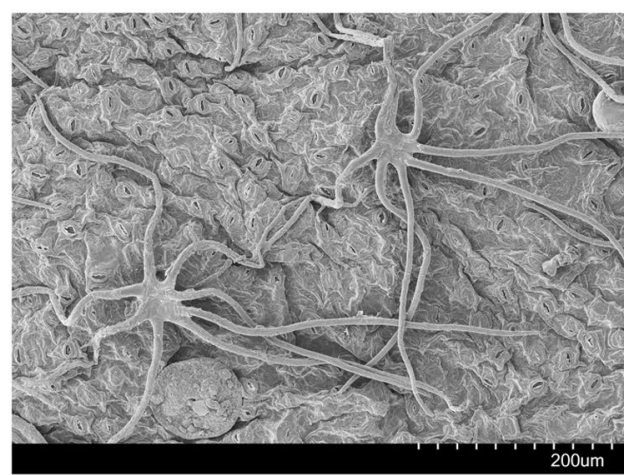

f

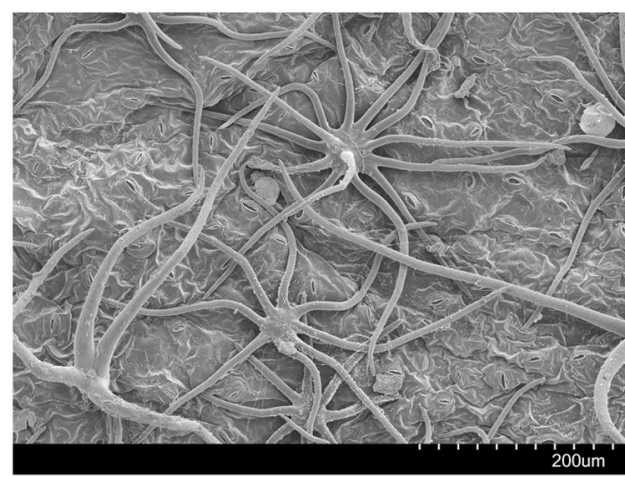

h

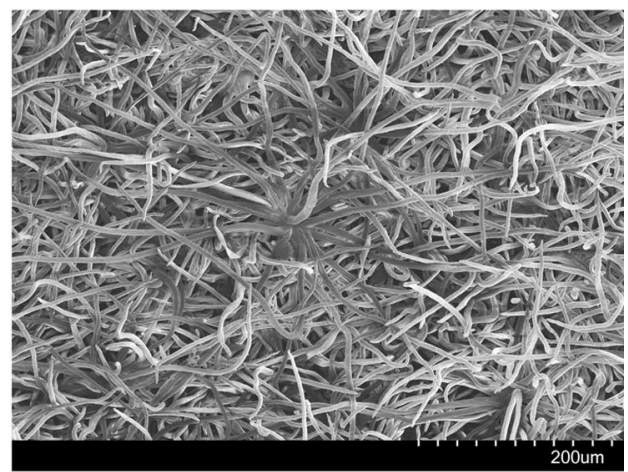

in each of three populations (field sample 3 in populations 1,11 and 115 , see below); (1) the same branch was classified twice on different occasions, and (2) an additional branch of the same specimen was also classified. The specimens were given a random code number to prevent my knowledge of their population identity causing bias in my classification. Comparison of the two classifications of the same branch is a test of the repeatability of the method, and comparing (1) and (2) gives information of the degree of variation within plants. 


\section{Crossing experiments}

Plants were transferred to a heated, insect-free greenhouse in April (Table 1). To optimise synchrony of flowering between plants $(n=12)$ in the crossing programme (see Testing inheritance of pubescence, below), replicates of individual plants were transferred to the greenhouse within a 2-week period. At least one replicate of each plant used in the crossing programme was checked for autogamous selffertilisation by leaving it as a control, untreated and isolated in the cultivation chamber. Reciprocal crosses were performed between plants in different combinations within and between populations by gently rubbing flowers from two plants with synchronised flowering. By using replicates, individual plants could be included in several crossing combinations. To avoid contamination, the two parental plants in each cross were separated from other combinations of plants by distances of several metres in the cultivation chamber. A few inflorescences not used for the crosses on individual plants were left untouched as an extra control of contamination. Seeds were harvested after 5-6 weeks.

The seed coat was rubbed with sandpaper to break dormancy. Seeds of the F1 generation were usually sown for the first time on petri dishes or in pots indoors or outdoors in spring of the year after the cross was performed. Because the seedlings were sensitive to drought and slug grazing, and because many died before establishment, only small batches of the seeds $(n=10-20)$ from each cross were sown each year. It usually took 2 years (sometimes more) for a cohort of the seedlings to reach flowering. The F2 generation was produced by pairwise crosses among $\mathrm{F} 1$ plants within families (usually 5-6 siblings in each family). Several crosses had to be repeated in successive years, because of problems with synchronising flowering among siblings and because some of the crosses between siblings were unsuccessful. Consequently, an F2 generation could usually not be produced until 3-5 years after the original cross. A few inflorescences of F1 plants not used in crosses were left as controls of self-compatibility, and other inflorescences not used in the crosses were removed before flowering.

Seeds of the F2 generation were treated in the same way as those in F1. At least one, often two, vouchers of each plant were pressed and preserved. Classification of pubescence of the progeny in F1 and F2 followed the procedure described above. Plants were classified provisionally at first when they had reached a minimum age of 1 year, but the final classification of all plants was performed on adults when the crossing programme was completed.

\section{Testing inheritance of pubescence}

Widén (2015) showed that inheritance of pubescence was governed by a Mendelian gene with two alleles in $\mathrm{H}$. nummularium. I posed the same 'a priori' hypothesis that the inheritance of a dense cover of stellate hairs on the abaxial surface of the leaves is determined by a recessive allele of a Mendelian gene in $H$. oelandicum var. canescens. I used plants from two homogeneous populations: four plants from population 11, where most plants had a dense cover of stellate hairs on the abaxial surface of the leaves, and three plants from population 1, where all plants lacked the dense cover of stellate hairs. Five additional plants were used in the crossing programme-three from two monomorphic populations (nos. 112 and 115) for the hairy plants and two plants without a dense cover of stellate hairs from two polymorphic populations (nos. 109 and 133). See Table 1.

To test the 'a priori' hypothesis, the following four types of crosses between morphs within and between populations were performed:

1. Crosses between plants with a dense cover of stellate hairs on the abaxial surface of the leaves (for simplicity, referred to as 'stellated plants'). All plants were from monomorphic populations (nos. 11, 112 and 115), and
Table 1 Identity and characteristics of $H$. oelandicum var. canescens plants used in crosses

\begin{tabular}{llclll}
\hline Population & Type of population & Plant & Hair score & Phenotype & Assumed genotype \\
\hline 1 & Monomorphic & 6331 & 0 & Bristled & Brist/Brist \\
1 & Monomorphic & 4991 & 0 & Bristled & Brist/Brist \\
1 & Monomorphic & 4992 & 1 & Bristled & Brist/Brist \\
11 & Monomorphic & 4978 & 3 & Stellated & can/can \\
11 & Monomorphic & 6359 & 3 & Stellated & $\mathrm{can} / \mathrm{can}$ \\
11 & Monomorphic & 9364 & 3 & Stellated & $\mathrm{can} / \mathrm{can}$ \\
11 & Monomorphic & 6390 & 3 & Stellated & $\mathrm{can} / \mathrm{can}$ \\
112 & Monomorphic & 10,640 & 3 & Stellated & $\mathrm{can} / \mathrm{can}$ \\
112 & Monomorphic & 9380 & 3 & Stellated & $\mathrm{can} / \mathrm{can}$ \\
115 & Monomorphic & 3609 & 3 & Stellated & $\mathrm{can} / \mathrm{can}$ \\
109 & Polymonomorphic & 3874 & 0 & Bristled & Brist/Brist \\
133 & Polymonomorphic & 9331 & 1 & Bristled & Brist/can \\
\hline
\end{tabular}


they were assumed to be homozygous for the recessive allele determining the dense cover of stellate hairs.

2. Crosses between plants from a monomorphic population (no. 1) with plants without a dense cover of stellate hairs on the abaxial surface of the leaves (for simplicity, 'bristled plants'). All plants were assumed to be homozygous for the dominant allele determining the lack of a dense cover of stellate hairs.

3. Crosses between plants from one monomorphic population (no. 1) of bristled plants and two monomorphic populations (nos. 11 and 112) of stellated plants. The plants were assumed to be homozygous for the dominant and recessive alleles, respectively.

4. Crosses between plants from four monomorphic populations (nos. 1, 11, 112 and 115) and bristled plants from two polymorphic populations (nos. 109 and 133). Plants from the monomorphic populations were assumed to be homozygous for the dominant and recessive alleles, respectively (see above), while plants from the polymorphic populations could be either homo- or heterozygous for the dominant allele (cf. Table 1).

\section{Allele frequencies in natural populations}

Variation in hairs was translated to allele frequencies in different samples. The allele frequencies $[q=\sqrt{ }$ (number of stellate plants $/ n)$ ] were estimated assuming Hardy-Weinberg equilibrium (H. oelandicum is self-incompatible, see below). Samples within and between populations were compared. The allele frequencies in sample 1 for different sites were displayed on a map (Fig. 1d).

\section{Statistical tests}

Differences in the distribution of hair scores among samples within sites, as well as among crosses, were tested using a nonparametric test, the Kruskal-Wallis test, while pairwise comparisons were done using a Mann-Whitney $U$ test. The results of experimental crosses were evaluated by testing the goodness of fit of observed frequencies of the two hair morphs according to the 'a priori' hypothesis described above.

\section{Results}

\section{Quantification of pubescence}

When I tested the repeatability of the classification of hairs by measuring the same branch on 60 plants on two different occasions, the hair score was the same in $71.2 \%$ of the cases. The differences between the two classifications were 0.5 in $27.1 \%$ of the cases. The corresponding proportions were 61.0 and $33.1 \%$ when two different branches on a plant were classified $(n=60)$. Consequently, the probability was high $(p \approx 0.95)$ that repeated measures of an individual were the same or within \pm 0.5 scores.

The distribution of hair scores for the six populations used in the crossing programme is illustrated in Fig. 4. Three populations represented areas with the most pubescent plants (nos. 11, 112 and 115) and one population (no. 1) represented areas with the least hairy plants. These populations are classified as monomorphic (Table 1). Two populations (nos. 109 and 133) had a mixture of plants with respect to hairiness and were therefore classified as polymorphic (Table 1). In population 1-with only bristled plants-the distribution of hair scores ranged from 0 to 1.5. Population 112 had only stellated plants; here the distribution of hair scores ranged from 2 to 3 . Most plants had a hair score in the range $2-3$ in the two other populations dominated by stellated plants (nos. 11 and 115). The hair scores ranged from 0 to 3 in the two polymorphic populations (nos. 109 and 133).

Hairiness of plants in several samples from the same site $(100 \times 100 \mathrm{~m})$ could be compared in three of the populations in Fig. 4. The distribution of hair scores for plants in the common garden sample did not differ significantly from that of the field sample 1 (the seed source of the cultivated plants) in population 1 (Mann-Whitney $U$ test $=176.0$, $p=0.869)$, but the difference was marginally significant in population 11 (Mann-Whitney $U$ test $=247.0, p=0.046$ ). When the three field samples within populations were compared, samples in population 1 differed marginally significantly (Kruskal-Wallis test $=6.3, d f=2, p=0.043$ ), but not the samples in populations 11 and 115 (Kruskal-Wallis test $=3.18, d f=2, p=0.204$ and Kruskal-Wallis test $=5.12$, $d f=2, p=0.077$, respectively).

\section{Crosses}

\section{Self-incompatibility}

No replicate of the parental plants isolated in the cultivation chamber as control of autogamous self-fertilisation set seed. Very rarely one or a few seeds developed in a capsule on control inflorescences of parental plants and $\mathrm{F} 1$ progeny used in a cross.

\section{Segregation in crosses}

The reciprocals set seeds in most crosses between parental plants, but crosses among progeny in F1 were sometimes unsuccessful and had to be repeated in alternative combinations among the progeny. Different cohorts of a given cross were sometimes raised in different environments (outdoors or indoors), which could have influenced the hair score given to individual plants. However, when several vouchers of a 
Fig. 4 Distribution of hair scores at sites $(100 \times 100 \mathrm{~m})$ used for crosses between plants in Helianthemum olandicum var. canescens. a Three sites with several samples per site (nos. 1, 11 and 115). b Three sites with one sample per site (nos. 109, 112 and 133)
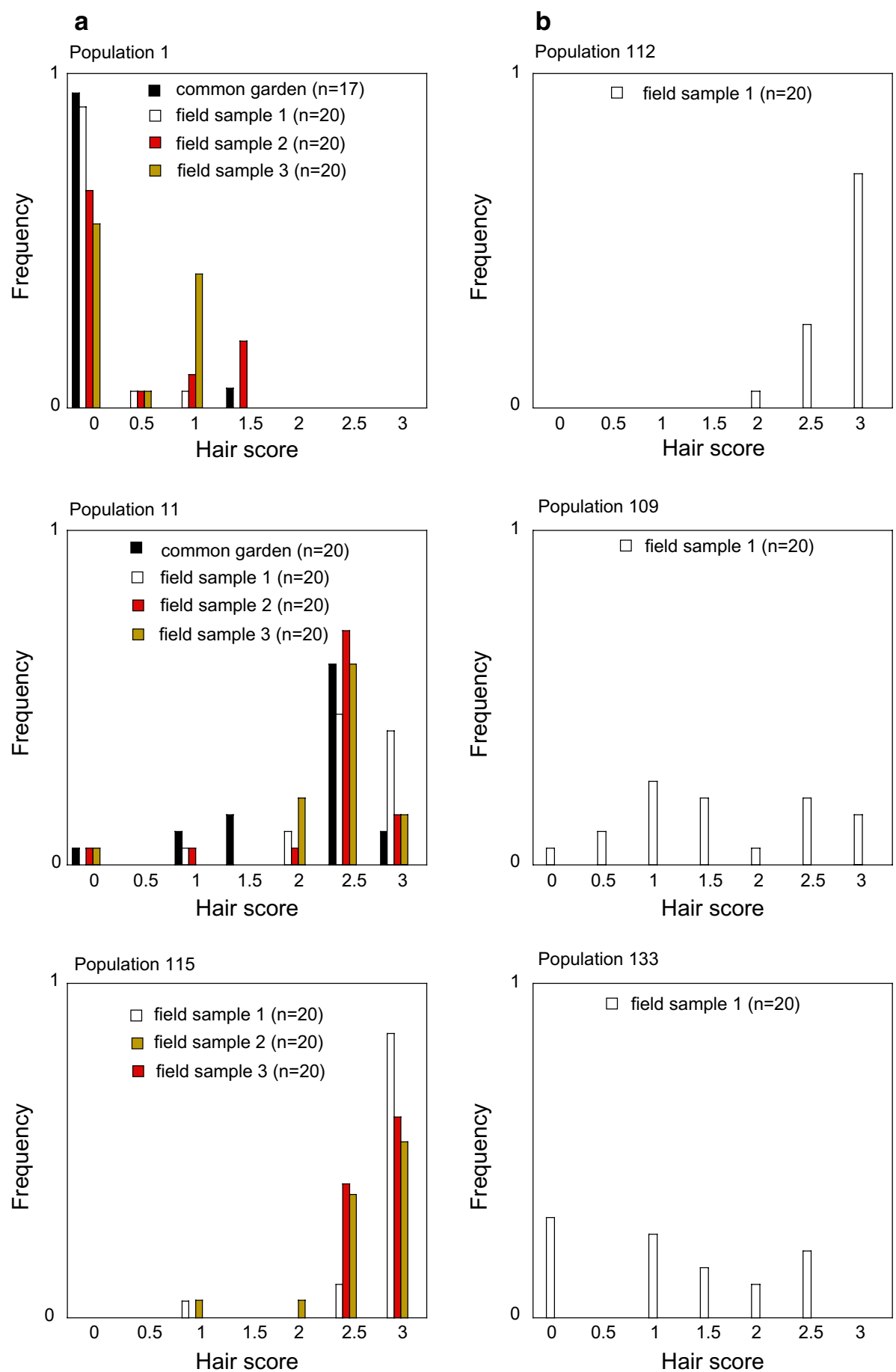

plant were preserved, their hair score did not differ more than \pm 0.5 . If possible, vouchers of plants raised indoors were used in the classification of hairs (most vouchers were sampled from progeny raised indoors).

The distribution of hair scores of offspring in crosses among plants within morphs did not differ between $\mathrm{F} 1$ and F2 (cross types 1 and 2; Tables 2, 3; Fig. 5a), confirming the assumption that mother plants were homozygotes for the dominant and the recessive alleles, accordingly. The distribution of hair scores of offspring in F1s of crosses between the two morphs from different monomorphic populations was the same among crosses (cross type 3; Table 4) and did not differ from the distribution of hair scores of $\mathrm{F} 1$ progeny in crosses among bristled plants (cross type 2; Fig. 5b, Mann-Whitney $U$ test $=9799.5, n=333$, $p=0.959)$. Genes that determine hairiness of bristled plants are dominant over genes that determine hairiness of stellated plants. 
Table 2 Crosses among stellated plants derived from monomorphic populations (cross type 1)

\begin{tabular}{|c|c|c|c|c|c|c|c|c|}
\hline \multirow[t]{2}{*}{ Hair score } & \multicolumn{2}{|c|}{ Cross 10} & \multicolumn{2}{|c|}{ Cross 50} & \multicolumn{2}{|c|}{ Cross 63} & \multicolumn{2}{|c|}{ Cross 96} \\
\hline & F1 & $\mathrm{F} 2$ & $\mathrm{~F} 1$ & $\mathrm{~F} 2$ & $\mathrm{~F} 1$ & $\mathrm{~F} 2$ & $\mathrm{~F} 1$ & $\mathrm{~F} 2$ \\
\hline 0 & 0 & 0 & 0 & 0 & 0 & 0 & 0 & 0 \\
\hline 0.5 & 0 & 0 & 0 & 0 & 0 & 0 & 0 & 0 \\
\hline 1 & 0 & 0 & 0 & 0 & 0 & 0 & 0 & 0 \\
\hline 1.5 & 0 & 0 & 0 & 0 & 0 & 0 & 0 & 0 \\
\hline 2 & 0 & 0 & 0 & 0 & 0 & 1 & 1 & 0 \\
\hline 2.5 & 13 & 0 & 3 & 5 & 1 & 4 & 15 & 20 \\
\hline 3 & 22 & 2 & 39 & 19 & 24 & 33 & 86 & 54 \\
\hline Sum & 35 & 2 & 42 & 24 & 25 & 37 & 102 & 74 \\
\hline \multicolumn{3}{|c|}{$\begin{array}{l}\text { Mann-Whitney } U \\
\text { test } p\end{array}$} & \multicolumn{2}{|c|}{0.104} & \multicolumn{2}{|c|}{0.224} & \multicolumn{2}{|c|}{0.073} \\
\hline
\end{tabular}

The difference in distribution of hair scores for F1 and F2 in each cross was tested with Mann-Whitney $U$ test

\begin{tabular}{|c|c|c|c|c|}
\hline \multirow[t]{2}{*}{ Hair score } & \multicolumn{2}{|c|}{$\begin{array}{l}\text { Cross } \\
16\end{array}$} & \multicolumn{2}{|c|}{ Cross 45} \\
\hline & $\mathrm{F} 1$ & $\mathrm{~F} 2$ & F1 & $\mathrm{F} 2$ \\
\hline 0 & 15 & 16 & 24 & 26 \\
\hline 0.5 & 16 & 32 & 18 & 21 \\
\hline 1 & 0 & 0 & 3 & 2 \\
\hline 1.5 & 0 & 0 & 0 & 0 \\
\hline 2 & 0 & 0 & 0 & 0 \\
\hline 2.5 & 0 & 0 & 0 & 0 \\
\hline 3 & 0 & 0 & 0 & 0 \\
\hline Sum & 31 & 48 & 45 & 49 \\
\hline
\end{tabular}

The distribution of hair scores is the same across the four categories (F1 and F2 of the two crosses). Kruskal-Wallis test, $p=0.323$
F2 progeny in crosses between bristled plants and stellated plants from monomorphic populations segregated the whole range of hair scores (cross type 3; Table 4; Fig. 5b). The distribution of hair scores among the six crosses was significantly different (Table 4). By comparing the distribution of hair scores in crosses within morphs (cross types 1 and 2; Fig. 5a) with that of crosses between morphs (cross type 3 ; Fig. 5b), I classified plants with hair scores $\leq 1.5$ as bristled plants and plants with hair scores $\geq 2$ as stellated plants. The number of bristled F2 plants was 314, and the number of stellated F2 plants was 116 in the six F2 families of cross type 3 ; the segregation did not differ from the expected 3:1 ratio according to the 'a priori' hypothesis $\left(X^{2}=0.90, \mathrm{~ns}\right)$. The segregations in separate crosses did not differ from the expected 3:1 ratio (Tables 5). The phenotype of bristled plants (hair scores $\leq 1.5$ ) is determined by a dominant allele, and the phenotype of stellated plants (hair scores $\geq 2$ ) is determined by a recessive allele.
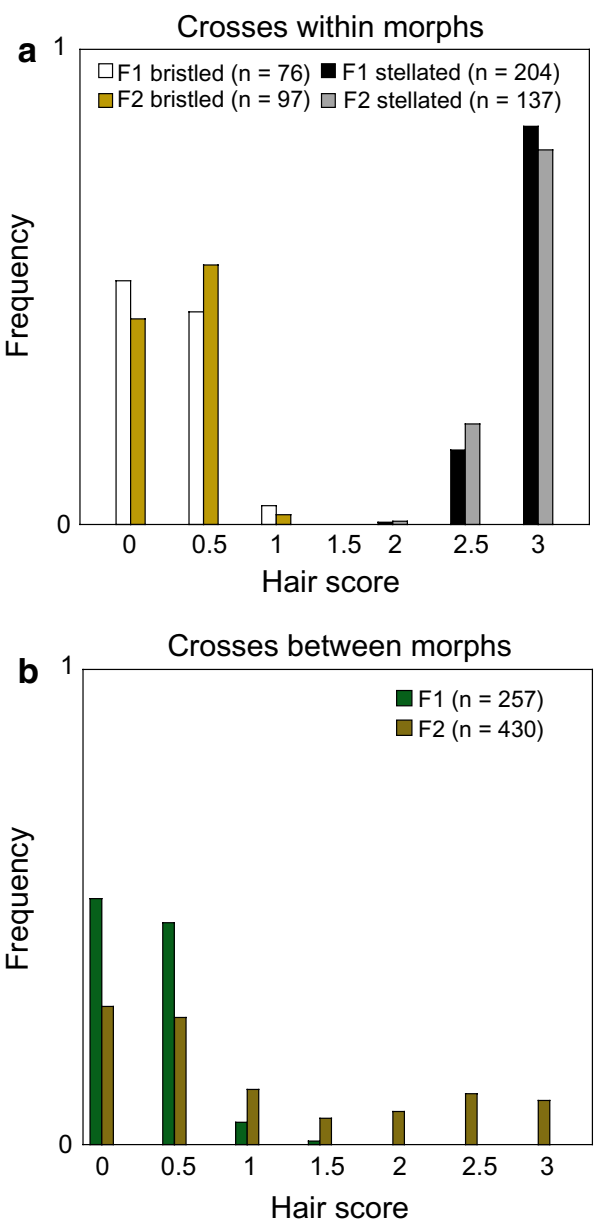

Fig. 5 Summary of hair scores in crosses in Helianthemum olandicum var. canescens between plants from monomorphic populations. a Crosses among bristled and stellated plants, respectively. b Crosses between bristled and stellated plants 
Table 4 Crosses between bristled and stellated morphs derived from monomorphic population (cross type 3 )

\begin{tabular}{|c|c|c|c|c|c|c|c|c|c|c|c|c|c|c|}
\hline \multirow[t]{2}{*}{ Hair score } & \multicolumn{2}{|c|}{ Cross 2} & \multicolumn{2}{|c|}{ Cross 11} & \multicolumn{2}{|c|}{ Cross 18} & \multicolumn{2}{|c|}{ Cross 20} & \multicolumn{2}{|c|}{ Cross 44} & \multicolumn{2}{|c|}{ Cross 93} & \multicolumn{2}{|c|}{ Cross 98} \\
\hline & $\mathrm{F} 1$ & $\mathrm{~F} 2$ & $\mathrm{~F} 1$ & $\mathrm{~F} 2$ & $\mathrm{~F} 1$ & $\mathrm{~F} 2$ & $\mathrm{~F} 1$ & $\mathrm{~F} 2$ & $\mathrm{~F} 1$ & $\mathrm{~F} 2$ & $\mathrm{~F} 1$ & $\mathrm{~F} 2$ & $\mathrm{~F} 1$ & $\mathrm{~F} 2$ \\
\hline 0 & 36 & 30 & 16 & - & 20 & 1 & 24 & 26 & 11 & 14 & 3 & 20 & 23 & 34 \\
\hline 0.5 & 30 & 24 & 18 & - & 14 & 12 & 20 & 27 & 7 & 23 & 2 & 9 & 29 & 20 \\
\hline 1 & 1 & 6 & 1 & - & 2 & 11 & 5 & 14 & 2 & 15 & 0 & 4 & 1 & 1 \\
\hline 1.5 & 0 & 1 & 0 & - & 0 & 7 & 0 & 6 & 2 & 10 & 0 & 0 & 0 & 0 \\
\hline 2 & 0 & 6 & 0 & - & 0 & 3 & 0 & 8 & 0 & 5 & 0 & 1 & 0 & 7 \\
\hline 2.5 & 0 & 8 & 0 & - & 0 & 4 & 0 & 5 & 0 & 11 & 0 & 6 & 0 & 12 \\
\hline 3 & 0 & 13 & 0 & - & 0 & 5 & 0 & 4 & 0 & 12 & 0 & 6 & 0 & 0 \\
\hline Sum & 57 & 88 & 35 & - & 36 & 43 & 49 & 90 & 22 & 90 & 5 & 46 & 53 & 74 \\
\hline
\end{tabular}

The distribution of hair scores is the same across the seven F1 families (Kruskal-Wallis test statistics $=5856, p=0.323$ ), while the distribution of hair scores differs among the six F2 families (KruskalWallis test statistics $=30,145, p=0.000$ )
In cross no. 95, between a bristled plant (no. 3874 in Table 5) from the polymorphic population 109 and a bristled plant from the monomorphic population 1, neither F1 nor F2 segregated. When plant no. 3874 was crossed with two stellated plants (cross nos. 94 and 97 in Table 5), the progeny in F1 was all bristled plants (Table 6) and the segregation in F2 did not deviate from the expected 3:1 ratio (Table 5). Plant no. 3874 from the polymorphic population 109 was homozygous for the dominant allele. When the bristled plant no. 9331 from the polymorphic population 133 was crossed with the stellated plant no. 9364 from the monomorphic population 11 (cross no. 70), progeny in F1 segregated and the segregation did not deviate from 1:1, indicating that the bristled plant no. 9331 was heterozygous (Table 5). F2 progeny in cross no. 70 was produced by crossing a heterogeneous cohort of F1 plants, so segregation in F2 could not be tested against the 'a priori' hypothesis.

The inferred genotypes of an assumed major locus for the two hair phenotypes, bristled plants (Brist/Brist or Brist/ can) and stellated plants ( $\mathrm{can} / \mathrm{can}$ ), respectively, used in the crossing programme are shown in Table 1 . Segregation in all crosses was in accordance with the inferred genotypes (Tables 1,5).

\section{Allele frequencies in natural populations}

Using plants with hair scores $\geq 2$ as an estimation of the recessive homozygotes, I calculated the frequency of the recessive (can) allele in the field samples and the common garden sample (Table 7). There was a significant correlation $(r=0.877, p<0.01)$ between the estimated frequency of the can allele in natural populations based on field sample 1 and on the offspring in the common garden sample (Fig. 6). The correlations of allele frequencies among the three field samples within sites were highly significant (Table 8).
Estimation of the frequency of the can allele in field sample 1 differed among populations (Fig. 1; Table 7). The distribution of the can allele is geographically structured (Fig. 1d). The frequency of the recessive allele was equal to or greater than $50 \%$ in $65 \%$ of the populations. High frequency of the can allele was found especially in the northern part of the distribution area of $H$. oelandicum var. canescens (population nos. 11, 112 and 115). Population nos. 1 and 145 were the most extreme sites with a low frequency of the can allele (zero). In this isolated, southernmost alvar area, the can allele could be found in higher frequencies only at the margin of the area (populations nos. 144 and 149). Population no. 136, located very close to the transition zone between var. canescens and var. oelandicum, also showed a low frequency of the recessive allele. The marginal site no. 142 showed a remarkably high frequency of the can allele compared with more central sites in the same area.

\section{Discussion}

Local botanists have long recognised the morphological variation of $H$. oelandicum on the Baltic island of Öland. Sterner (1936b) pointed out that the late flowering morph (PF) consisted of two hair morphs, one with a dense cover of stellate hairs on the abaxial surface of the leaves and one without (see also Sjöstrand 1850). According to the species concept of that time, Sterner (1936b) suggested that three species occurred in the restricted area of Öland: the common H. oelandicum (L.) Willd. with the CF phenology and the two more restricted taxa with the PF phenology, H. italicum (L.) Pers. subsp. rupifragum (Kern.) Beger without a dense cover of stellate hairs on the abaxial surface of the leaves and H. canum (L.) Baumg. with that character. Widén (1980) emphasised the allopatric distributions of the two flowering morphs, and he surveyed the geographical pattern in pubescence of $H$. oelandicum on Öland. He also abandoned the 


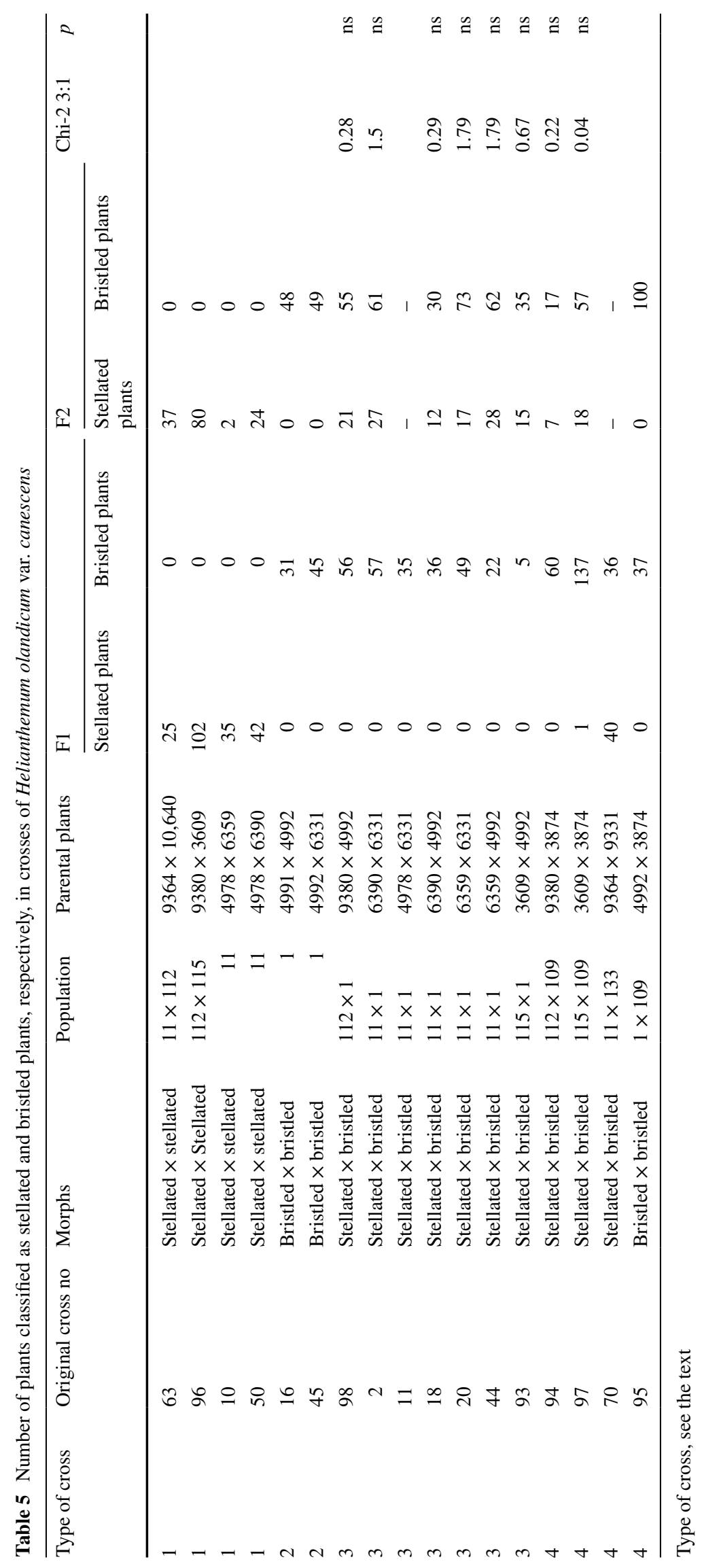


Table 6 Crosses between plants derived from monomorphic population and plants derived from polymorphic populations (cross type 4)

\begin{tabular}{|c|c|c|c|c|c|c|c|c|}
\hline \multirow[t]{2}{*}{ Hair score } & \multicolumn{2}{|c|}{ Cross 70} & \multicolumn{2}{|c|}{ Cross 94} & \multicolumn{2}{|c|}{ Cross 95} & \multicolumn{2}{|c|}{ Cross 97} \\
\hline & F1 & F2 & $\mathrm{F} 1$ & F2 & F1 & $\mathrm{F} 2$ & F1 & $\mathrm{F} 2$ \\
\hline 0 & 14 & 0 & 17 & 3 & 3 & 7 & 65 & 26 \\
\hline 0.5 & 13 & 10 & 39 & 11 & 15 & 78 & 56 & 28 \\
\hline 1 & 3 & 4 & 4 & 2 & 16 & 12 & 7 & 3 \\
\hline 1.5 & 0 & 15 & 0 & 0 & 3 & 0 & 0 & 0 \\
\hline 2 & 7 & 20 & 0 & 4 & 0 & 0 & 0 & 1 \\
\hline 2.5 & 9 & 26 & 0 & 1 & 0 & 0 & 0 & 9 \\
\hline 3 & 24 & 27 & 0 & 1 & 0 & 0 & 1 & 8 \\
\hline Sum & 70 & 102 & 60 & 22 & 37 & 97 & 129 & 75 \\
\hline
\end{tabular}

long tradition in the taxonomy of Helianthemum to use the dense cover of stellate hairs on the abaxial surface of the leaves as an important diagnostic character for the taxonomy of the Öland morphs.

Widén (1988) described variation in pubescence of $H$. oelandicum by using a hair index, which was the sum of hair scores describing the density of bristles and stellate hairs on leaves, peduncles and sepals. The high and significant correlation between hair scores on different parts of the plant (Widén 1988) implies that the hair score for the density of stellate hairs on the abaxial surface of the leaves used in the present study is representative of the total hairiness of a plant. The use of a template for the classification of the density of hairs, measured with a $95 \%$ probability interval of \pm 0.5 scores, makes it possible to survey the pubescence of thousands of plants within a reasonable time. Widén (1988) discussed the repeatability and reliability of the use of hairs scores to describe variation in pubescence of Helianthemum.

\section{Phenotypic plasticity}

Young leaves are usually more hairy than older leaves, and fast-growing leaves on stellated plants in cultivation are less hairy than plants in more stressful environments in natural populations. Cultivated bristled plants, on the other hand, tend to have a denser cover of hairs than plants in natural populations (B. Widén, personal observation). However, this variation is subtle and difficult to quantify with the methods used in the present study. When individual plants were classified in different environments (cultivated indoors or outdoors), their hair scores sometimes differed, but the differences rarely exceeded 0.5 . Consequently, the phenotypic plasticity of hair density is not large enough to bias the classification of individuals into bristled and stellated plants.

\section{Inheritance}

Helianthemum oelandicum var. canescens is self-incompatible, and no emasculation is needed in crosses between plants. The few seeds that occasionally developed in capsules on control inflorescences of experimental plants were probably the result of contamination of pollen from the crosses. However, the experimental set-up with well-spaced groups of plants (individual crosses) minimised the risk of contamination between crosses.

Several genes determine the inheritance of pubescence in Helianthemum. The presence/absence of a dense cover of stellate hairs on the abaxial surface of the leaves in $H$. oelandicum var. canesens is determined by one major gene with two alleles, and the density of hairs seems to be quantitative or involves several genes of small effect. The inheritance of hair density is complex; different crosses between bristled and stellated plants tended to give F2 progeny with a significantly different distribution of hair scores. The exact mechanism of the gene(s) determining the density of hairs, however, needs further studies. The major Mendelian gene with two alleles (or alleles with the same phenotypic expression) is widespread in Helianthemum (Widén 2015; unpublished). The distribution of hair scores in crosses between H. nummularium subsp. nummularium and subsp. obscurum (Fig. 3 in Widén 2015) is very similar to the distribution of hair scores in crosses between bristled and stellated plants in the present study. The tradition in the taxonomy of Helianthemum has long considered the phenotypes of the dominant and the recessive alleles to be diagnostically important (Janchen 1907; Proctor and Heywood 1968). The results in the present study support the conclusions in Widén (2015) and in Soubani et al. (2015) that the genetic variation in pubescence should be considered in an adaptive and postglacial migration context, and not primarily in a taxonomical context (see also Volkova et al. 2016).

\section{Geographical pattern in allele frequencies}

Widén (1988) pointed out the distinct geographical pattern in the distribution of plants with different kinds of hairs in H. oelandicum on the Baltic island of Öland. Here I have translated variation in stellate hairs into allele frequencies of a Mendelian gene in $H$. oelandicum var. canesens. The result shows that the recessive allele (can) is virtually exclusive in 


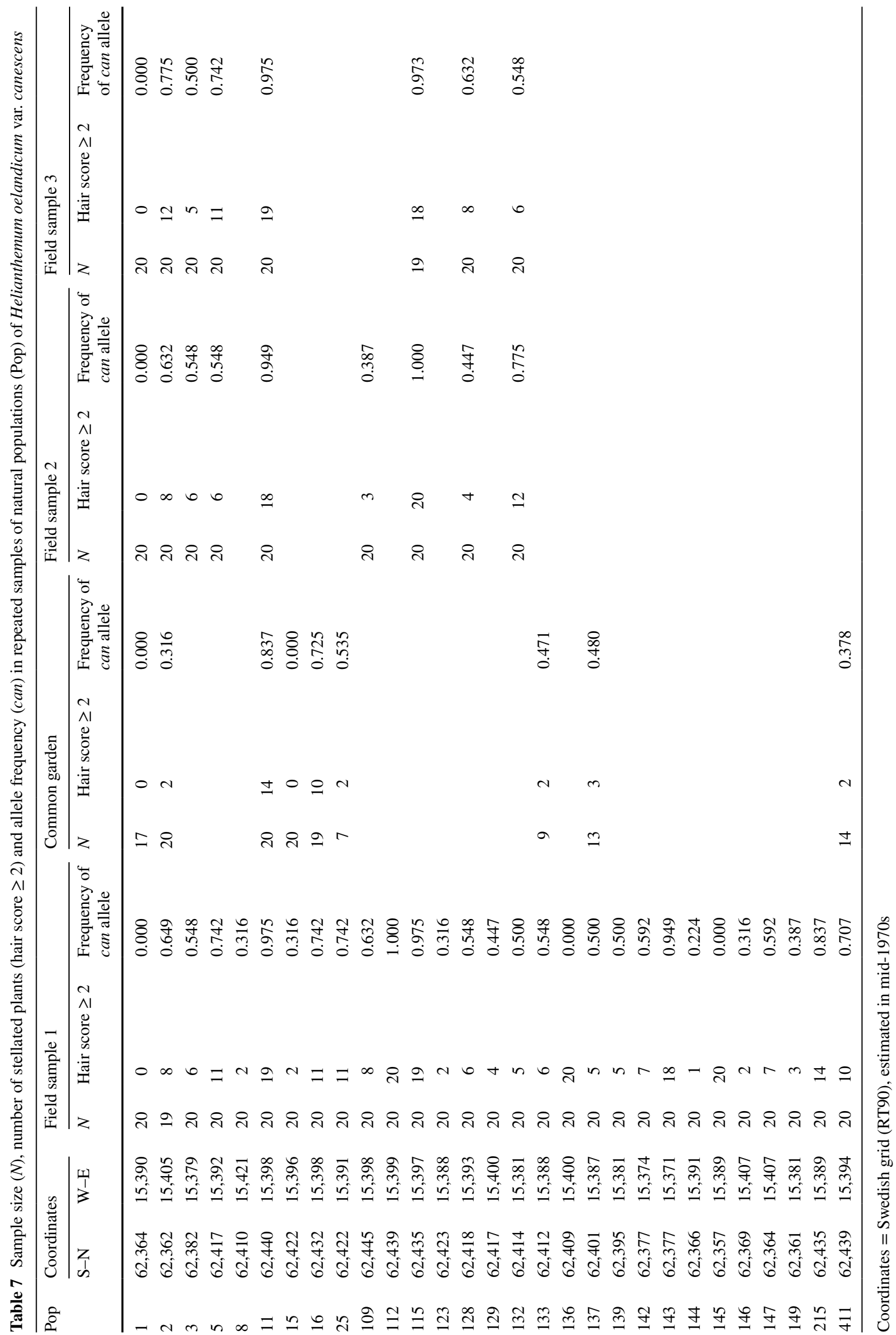




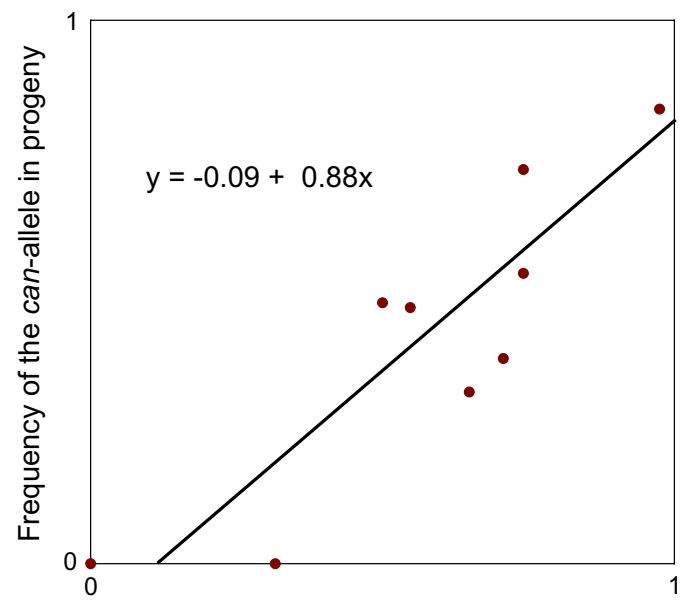

Frequency of the can-allele in natural populations

Fig. 6 Estimation of frequency of the recessive can allele for a dense cover of stellate hairs on the abaxial surface of the leaves in Helianthemum olandicum var. canescens, based on the field sample 1 and on the common garden sample in 9 populations. The correlation between the frequencies $(0.877)$ is significant at $p<0.01$

Table 8 Correlation of allele frequencies between samples within populations (cf. Table 7)

\begin{tabular}{llll}
\hline Correlation between & $r$ & $p$ & $N$ \\
\hline Field sample 1 and common garden sample & 0.877 & 0.002 & 9 \\
Field sample 1 and field sample 2 & 0.877 & 0.002 & 9 \\
Field sample 1 and field sample 3 & 0.984 & 0.000 & 8 \\
Field sample 2 and field sample 3 & 0.900 & 0.002 & 8 \\
\hline
\end{tabular}

the northernmost part of the distribution area of var. canesens-an area about $1 \mathrm{~km}^{2}$. The frequency of the can allele varies around $50 \%$ in most other parts of the distribution area of this variety, except for one of the southernmost alvar fragments, where the can allele is virtually lacking in thousands of $\mathrm{m}^{2}$ of flat, homogenous alvar habitats.

Two plastid haplotypes have been found in $\mathrm{H}$. oelandicum on Öland. The western haplotype occurs in both H. oelandicum var. oelandicum and var. canescens, whereas the eastern plastid haplotype is only found in var. oelandicum (Soubani 2010). Helianthemum oelandicum arrived early on Öland when the ice withdrew after the LGM (Königsson 1968), but we do not know the morphology of the postglacial migrants, nor do we know which haplotype lineage arrived first (see Soubani 2010). Based on the present distribution of taxa in the H. oelandicum complex in western and central Europe, it is plausible to assume that the western haplotype was represented by a morph homozygous for the can allele (B. Widén, unpublished). The eastern lineage would then have been homozygous for an alternative dominant allele, giving rise to bristled leaves, since the can allele is now lacking in H. oelandicum var. oelandicum on Öland (Widén unpublished). The problem with the above scenario is that we cannot translate the present-day taxonomy of $H$. oelandicum to the morphology of the postglacial migrating lineages; taxa with the PF phenology of var. canescens and taxa without a dense cover of stellate hairs of var. oelandicum cannot be found today in continental Europe north of the Alps (Widén unpublished).

\section{Habitat heterogeneity}

Helianthemum oelandicum is one of the dominant species in the dry, open grassland habitats of the alvar vegetation on Öland (Sterner 1936a; Bengtsson et al. 1988; Reitalu et al. 2014). The species occurs in a wide range of plant communities (Bengtsson et al. 1988), from grasslands in well-drained glaciofluvial deposits with dense vegetation and high species diversity to species-poor vegetation in flat, poorly drained, more or less bare rock surfaces characterised by long periods of high water table and freezing and thawing during winter (Widén 1988). Clearly, H. oelandicum must cope with a broad spectrum of abiotic stresses related to water regulation, from drought in summer to frost heaving in winter. Widén (1988) found a significant correlation between hairiness and environmental factors connected with drainage. There are parallel trends in the distribution of hairy plants in the two varieties on Öland (cf. Wood et al. 2005). More or less one hundred per cent of the plants were glabrous over large, flat and poorly drained Alvar areas flooded during long periods in the winter in var. oelandicum, whereas hairy plants (bristled) dominated well-drained habitats (Sterner 1936a; Widén 1988). The habitats of var. canescens were especially flat and poorly drained in populations 1 and 146 with a low frequency of the can allel, but well-drained in the northern part of the distributional area of var. canescens with a high frequency of the can allele. This indicates that plants of var. canescens with a dense cover of stellate hairs on the abaxial surface of the leaves were favoured in well-drained habitats and less hairy plants were favoured in poorly drained habitats. The mechanism behind this indumentum-habitat correlation is obscure; either natural selection acts on the hair gene(s) directly or it acts on genes linked to hair gene(s).

\section{Hybridisation and introgression}

Today, only the plastid haplotype of the western European lineage has been found in $H$. oelandicum var. canesens and in var. oelandicum in the southernmost part of Öland (Soubani 2010). Because both varieties are only represented by the western plastid haplotype in southern Öland, it is plausible to assume extensive (historical and/or current) 
gene flow between the two taxa. The partial separation of flowering time and the allopatric distributions of the two varieties (Widén 1980, 1986, unpublished) restrict current gene flow. Artificial crosses between the two morphs show no crossing barriers (Widén 1986). A plausible hypothesis is that the allele(s) for bristled leaves has been introgressed from var. oelandicum to var. canesens during the postglacial migration and the history of the species on Öland (Widén unpublished).

A similar scenario on a larger geographical scale has been suggested for $H$. nummularium in southern Scandinavia (Soubani et al. 2015; Volkova et al. 2016). A western migration lineage represented by $H$. nummularium subsp. obscurum with a green abaxial surface of the leaves (without a dense cover of stellate hairs) has met an eastern lineage in form of $H$. nummularium subsp. nummularium with a whitish abaxial surface of the leaves (with a dense cover of stellate hairs). The whitish abaxial surface of the leaves is controlled by a recessive allele (can) of a major Mendelian gene (Widén 2015). The frequency of the can allele varies in natural populations of $H$. nummularium in a wide geographical zone in southern Sweden indicating extensive hybridization between two postglacial migration lineages (Soubani et al. 2015). The similarities between the two species, $H$. oelandicum and $H$. nummularium, in the genetic background of a trait frequently used in the taxonomy of the genus Helianthemum suggest that a major Mendelian gene influencing pubescence is widespread in the genus.

\section{Evolutionary implications}

The genus Helianthemum contains several young species complexes (Guzmán and Vargas 2009; Aparicio et al. 2017) with a wide Mediterranean and/or temperate/alpine distribution (e.g. H. apenninum Mill, H. cinereum Pers., $H$. nummularium, $H$. marifolium Mill. and $H$. oelandicum). Helianthemum oelandicum belongs to a very polymorphic group of species/subspecies including, e.g. $H$. cinereum, $H$. hymettium Boiss. and Heldr. and H. marifolium that did not show any significant terminal resolution in the trees of a recent phylogenetic reconstruction. The poor resolution was ascribed to Pleistocene radiation and events of reticulate evolution (Aparicio et al. 2017). The taxonomic treatment of these species complexes in both traditional and recent botanical literature has partly been based on diagnostic traits related to the presence and type of indumentum (e.g. Janchen 1907; Proctor and Heywood 1968). The two species complexes $H$. nummularium and $H$. oelandicum with the widest geographical distribution and belonging to different sections of the genus are of special interest. Recent studies based on samples covering large parts of their distributions have shown poor correlations between indumentum and size of leaves and petals (taxon identity) and plastid haplotypes (Soubani 2010; Soubani et al. 2014; Volkova et al. 2016), indicating extensive hybridization between taxa/morphs in both species. Experimental studies have shown weak crossing barriers within the two species (Widén 1986, 2015, unpublished). Despite circumstantial evidence of gene flow between morphs within the two species complexes, the apparent morphological integrity of taxa across their ranges suggests that natural selection plays a significant role in the morphological diversity of the species. The mechanisms and processes behind the diversity of $H$. oelandicum on Öland can serve as a model for the diversity within the whole $H$. oelandicum complex as well as diversity within other species complexes of Helianthemum. The two species $H$. nummularium and $H$. oelandicum, for example, have morphs in lowland and alpine habitats which show parallel trends in pubescence; alpine taxa are less hairy than lowland taxa (cf. H. nummularium subsp. nuтmиlarium vs subsp. glabrum (Koch) Wilczek and H. oelandicum subsp. incanum (Willk.) G.López vs subsp. alpestre (Jacq.) Breistr. Natural selection acting on a major hair gene would be an example of parallel adaptation sensu Wood et al. (2005).

This study adds to an increasing number of investigations that show diagnostic characters used to differentiate plant species and subspecies to be governed by single genes (Hilu 1983; Gottlieb 1984; Levin 2001). Hairs are present in most plant families, and their density and morphology have been considered important both in a taxonomic and in an adaptive context (cf. Levin 1973). The increasing number of studies showing indumentum to be controlled by single genes (e.g. Westerberg 1992; Silvestre 2000; Kärkkäinen and Ågren 2002; Kivmäki et al. 2007; Yol and Uzun 2011; Widén 2015) will contribute to a better understanding of the evolutionary significance of hairs and probably influence how pubescence is used in taxonomy and phylogenetic reconstruction in plants.

Acknowledgements I thank Lund University for greenhouse and common garden facilities from the early 1970s to the present day and the former ecological station of Uppsala University and the Station Linné research station for providing a base during the fieldwork on Öland. I acknowledge the Microscopy Facility at the Department of Biology, Lund University for the SEM photographs. I thank Marie Widén for assistance in the field and the common garden, Torbjörn Säll for valuable comments on the manuscript, and CommunicAID for language review and revision. I also appreciate the constructive comments made by two anonymous reviewers.

\section{Compliance with ethical standards}

Conflict of interest The author declares that he has no conflict of interest.

Open Access This article is distributed under the terms of the Creative Commons Attribution 4.0 International License (http:// 
creativecommons.org/licenses/by/4.0/), which permits unrestricted use, distribution, and reproduction in any medium, provided you give appropriate credit to the original author(s) and the source, provide a link to the Creative Commons license, and indicate if changes were made.

\section{References}

Ågren J, Schemske D (1992) Artificial selection on trichome number in Brassica rapa. Theoret Appl Genetics 83:673-678

Ågren J, Schemske D (1993) The cost of defense against herbivores: an experimental study of trichome production in Brassica rapa. Amer Naturalist 141:338-350

Aparicio A, Martín-Hernanz S, Parejo-Farnés C, Arroyo J, Lavergne S, Yesilyurt EB, Zang M-L, Rubio E, Albaladejo RD (2017) Phylogenetic reconstruction of the genus Helianthemum (Cistaceae) using plastid and nuclear DNA-sequences: systematic and evolutionary inferences. Taxon 66:868-885. doi:10.12705/664.5

Bayer C, Kubitzki K (2003) Malvaceae. In: Kubitzki K, Bayer C (eds) The families and genera of vascular plants, V, flowering plants, dicotyledons: malvales, capparales and not-betalain caryophyllales. Springer, Berlin, pp 225-311

Bengtsson K, Prentice HC, Rosén E, Moberg R, Sjögren E (1988) The dry alvar grasslands of Öland: ecological amplitudes of plant species in relation to vegetation composition. Acta Phytogeogr Suec 76:21-46

Berglund BE (1966) Late-Quaternary vegetation in eastern Blekinge, south-eastern Sweden. A pollen-analytical study. 1. Late-glacial time. Opera botanica. A Societate Botanica Lundensi in Supplementum Seriei 12:1-79

Espigares T, Peco B (1995) Mediterranean annual pasture dynamics: impact of autumn drought. J Ecol 83:135-142

Gottlieb LD (1984) Genetics \& morphological evolution in plants. Amer Naturalist 123:681-709

Grosser W (1903) Cistaceae. In: Engler A (ed) Pflanzenreich IV:193. W. Engelmann, Leipzig, pp 1-161

Guzmán B, Vargas P (2009) Historical biogeography and character evolution of Cistaceae (Malvales) based on analysis of plastid $r b c L$ and $t r n L-t r n F$ sequences. Organisms Diversity Evol 9:83-99. doi:10.1016/j.ode.2009.01.001

Hagley EAC, Bronskill JF, Ford EJ (1980) Effect of the physical nature of leaf and fruit surfaces by the codling moth, Cydia pomonella (Lepidoptera: Tortricidae). Canad J Entomol 112:503-510

Hilu KW (1983) The role of single-gene mutations in the evolution of flowering plants. Evol Biol 36:97-128

Janchen E (1907) Helianthemum canum (L.) Baumg. und seine nächsten verwandten. Abh Zool-Bot Ges Österreich 4:1-67

Kärkkäinen K, Ågren J (2002) Genetic basis of trichome production in Arabidopsis lyrata. Hereditas 136:219-226. doi:10.1034/j.1601-5223.2002.1360307.x

Kivmäki M, Kärkkäinen K, Gaudeul M, Løe G, Ågren J (2007) Gene, phenotype and function. GLABROUS1 and resistance to herbivory in natural populations of Arabidopsis lyrata. Molec Ecol 16:453-462. doi:10.1111/j.1365-294X.2007.03109.x

Königsson L-K (1968) The Holocene history of the Great Alvar of Öland. Acta Phytogeogr Suec 55:1-172

Larkin JC, Young N, Prigge M, Marks MD (1996) The role of trichome spacing and number in Arabidopsis. Development 122:997-1005

Levin DA (1973) The role of trichomes in plant defense. Quart Rev Biol 48:3-15

Levin DA (2001) The recurrent origin of plant races \& species. Syst Bot 26:197-204. doi:10.1043/0363-6445-26.2.197
Løe G, Toräng P, Gaudeul M, Ågren J (2007) Trichome production and spatiotemporal variation in herbivory in the perennial herb Arabidopsis lyrata. Oikos 116:134-142. doi:10.1111/j.2006.0030-1299.15022.x

Meagher RL, Smith CW, Smith WJ (1997) Preference of Gossypium genotypes to Bemisia argentifolii (Homoptera: Aleyrodidae). J Econ Entomol 90:1046-1052

Mortensen MF, Birks HH, Christensen C, Holm J, Noe-Nygaard N, Odgaard BV, Olsen J, Rasmussen KL (2011) Lateglacial vegetation development in Denmar-new evidence based on macrofossils and pollen from Slotseng, a small-scale site in southern Jutland. Quatern Sci Rev 30:2534-2550. doi:10.1016/j. quascirev.2011.04.018

Paliniswamy P, Bodnaryk RP (1994) A wild Brassica from Sicily provides trichome-based resistance against flea beetles, Phyllotreta cruciferae (Goeze) (Coleoptera: Chrysomelidae). Canad J Entomol 126:1119-1130

Proctor MCF, Heywood VH (1968) Helianthemum. In: Tutin TG, Heywood VH, Burges NA, Moore DM, Valentine DH, Walters SM, Webb DA (eds) Flora Europaea, vol. 2. Cambridge University Press, Cambridge, pp 286-291

Reitalu T, Helm A, Pärtel M, Bengtsson K, Gerhold P, Rosén E, Takkis K, Znamenskiy S, Prentice HC (2014) Determinants of finescale plant diversity in dry calcareous grasslands within the Baltic Sea region. Agric Ecosyst Environm 182:59-68. doi:10.1016/j. agee.2012.11.005

Silvestre S (2000) Taxonomic value of hairiness in Centranthus calcitrapae (L.) Dufresne fruits (Valerianaceae). Anales Jard Bot Madrid 58:239-244

Sjöstrand MG (1850) Enumeratio plantarum, in Ölandia sponte nascentium. Nova acta reg soc scient Upsaliensis, Uppsala

Skaltsa H, Verykokidou E, Harvala C, Krabourniotis D, Manetas Y (1994) UV-protective potential and flavonoid content of leaf hairs of Quercus ilex. Phytochemistry 37:987-990

Soubani E (2010) Systematics, phylogeography and multiple origins of morphs in two species complexes belonging to Cistaceae, Helianthemum oelandicum and $H$. nummularium. $\mathrm{PhD}$ thesis, Lund University, Lund

Soubani E, Hedrén M, Widén B (2014) Phylogeography of the European rock rose Helianthemum nummularium (Cistaceae): incongruent patterns of differentiation in plastid DNA and morphology. Bot J Linn Soc 176:311-331. doi:10.1111/boj.12209

Soubani E, Hedrén M, Widén B (2015) Genetic and morphological differentiation across a contact zone between two postglacial immigration lineages of Helianthemum nummularium (Cistaceae) in southern Scandinavia. Pl Syst Evol 301:1499-1508. doi:10.1007/ s00606-014-1170-1

Sterner R (1936a) Ekologiska iakttagelser över Helianthemum oelandicum (L.) Willd. Meddelande från Göteborgs Botaniska Trädgård XI, pp 183-208

Sterner R (1936b) Helianthemum oelandicum (L.) Willd. Och dess anförvanter på Öland. Svensk bot Tidskr 30:419-432

Svendsen JI, Alexanderson H, Astakhov VI, Demidov I, Dowdeswell JA, Funder S, Gataullin V, Henriksen M, Hjort C, HoumarkNielsen M, Hubberten HW, Ingólfsson Ó, Jakobsson M, Kjær KH, Larsen E, Lokrantz H, Lunkka JP, Lyså A, Mangerud J, Matiouchkov A, Murray A, Möller P, Niessen F, Nikolskaya O, Polyak L, Saarnisto M, Siegert C, Siegert MJ, Spielhagen RF, Stein R (2004) Late Quaternary ice sheet history of northern Eurasia. Quatern Sci Rev 23:1229-1271. doi:10.1016/j. quascirev.2003.12.008

Thanos CA, Georghiou K, Kadis C, Pantazi C (1992) Cistaceae: a plant family with hard seeds. Israel J Bot 41:251-263

Volkova PA, Schanzer IA, Soubani E, Meschersky IG, Widén B (2016) Phylogeography of the European rock rose Helianthemum 
nummularium s.1. (Cistaceae): western richness and eastern poverty. Pl Syst Evol 302:781-794. doi:10.1007/s00606-016-1299-1

Wagner GJ, Wang E, Shepherd RW (2004) New approaches for studying and exploiting an old protuberance, the plant trichome. Ann Bot (Oxford) 93:3-11. doi:10.1093/aob/mch011

Westerberg A (1992) The genetic basis of hairlessness in Silene dioica (Caryophyllaceae). Hereditas 117:287-291

Westerbergh A, Nyberg AB (1995) Selective grazing of hairless Silene dioica plants by land gastropods. Oikos 73:289-298

Widén B (1980) Flowering strategies in the Helianthemum oelandicum (Cistaceae) complex on Öland, Sweden. Bot Not 133:99-115

Widén B (1986) Biosystematics in the Helianthemum oelandicum complex on Öland. Symb Bot Upsal 27:53-60
Widén B (1988) Partitioning of variation in pubescence of a dwarf shrub, Helianthemum oelandicum. Acta Phytogeogr Suec 76:133-156

Widén B (2010) Cistaceae. In: Jonsell B, Karlsson T Flora Nordica 6. Swedish Museum of Natural History, Stockholm

Widén B (2015) Genetic basis of a key character in Helianthemum nummularium. Pl Syst Evol 301:1851-1862. doi:10.1007/ s00606-015-1198-x

Wood TE, Burke JM, Rieseberg LH (2005) Parallel genotypic adaptation: when evolution repeats itself. Genetica 123:157-170

Yol E, Uzun B (2011) Inheritance of number of capsules per leaf axil and hairiness on stem, leaf and capsules of sesame (Sesamum indicum L.). Austral J Crop Sci 5:78-81 